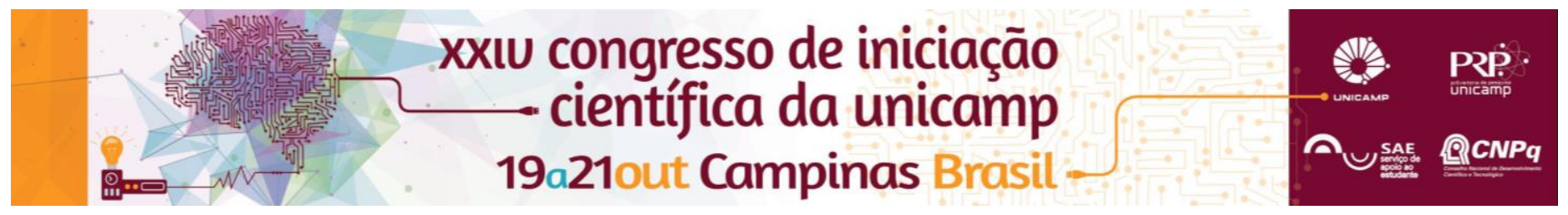

\title{
GESTOS DE CRIAÇÃO, CONEXÕES E DISPOSITIVOS
}

\section{Aline Mariane de Macêdo*, Barbara dos Santos, Livia Cuartero Gimenes, Prof. Dr. Carlos Eduardo A. Miranda}

\section{Resumo}

Este trabalho é a apresentação da atividade de conclusão da disciplina eletiva EP506 - Pedagogia da Imagem, ministrada das dependências da Faculdade de Educação da Unicamp, no 1ํsemestre de 2016, sob responsabilidade do Departamento de Educação, Conhecimento, Linguagem e Arte - DELART/FE/Unicamp.

\section{Palavras-chave}

Fotografia, Educação visual, Pedagogia da imagem.

\section{Introdução}

Fotografia, etimologicamente, pode ser pensada como a escrita com a luz, o desenho pelas linhas do visível e do invisível, do escondido e do revelado, num mundo de contrastes e rupturas a todo momento. Ao propor a fotografia como parte do processo de educação visual, compreende-se os percursos, as trajetórias e as vivências que cada história de vida sinaliza para pensar os processos de educação mais ampla. Neste sentido, o objetivo desta atividade é registrar cenas cotidianas, muitas vezes imperceptíveis aos olhos mais desavisados, por meio de dispositivos diversos, dentre eles uma folha de papel cartão, utilizado nas imagens a seguir.

\section{Resultados e Discussão}

As fotografias foram registradas nos espaços que compreende a Faculdade de Educação da Unicamp. Tais espaços estão permeados por elementos que consideramos essenciais no trabalho com educação visual, como folhas secas, espaço verde, grama, pedrinhas, terra, dentre outros. Vale a pena frisar que tais imagens foram capturadas como câmera digital comum.

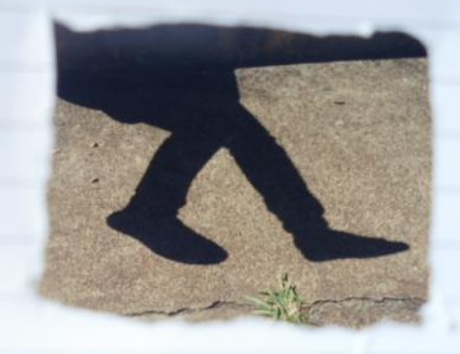

Figura 1. Sombra fotografada com o dispositivo folha de papel cartão.

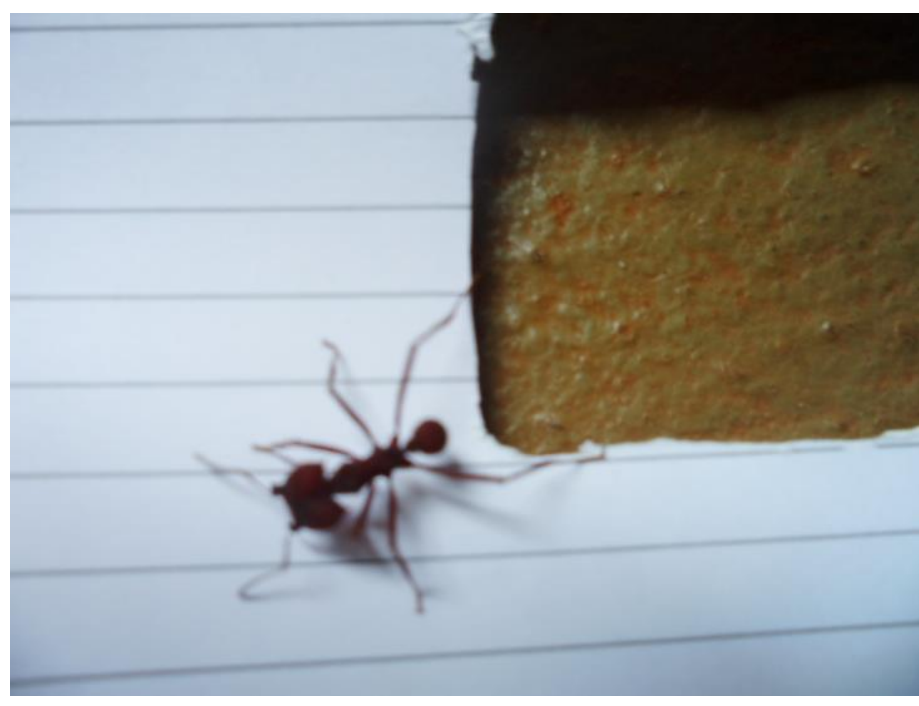

Figura 2. Formiga capturada pelo dispositivo folha de papel cartão.

\section{Conclusões}

A partir das fotografias realizadas no decorrer da disciplina, pudemos constatar o quanto o trabalho com imagens e vídeos pode ser proposto na escola básica, na qual é preciso reinventar os espaços, transformar o imaginário, a identidade e a busca por novos lugares e novas aspirações. Cada imagem produzida com os dispositivos pode ser pensada para além da imagem em $\mathrm{si}$, nas diversas possibilidades de trabalho com o olhar do outro, aquele que modifica, que ajuda a entender elementos desapercebidos.

\section{Agradecimentos}

À turma da disciplina EP506 - Pedagogia da Imagem, pelas discussões, leituras e saberes compartilhados.

COSTA, Ana Angélica Costa (Org.). Possibilidades da câmera obscura Campinas: Projeto Subsolo, 2015. 264 p.

MIGLIORIN, Cezar; PIPANO, Isaac; GARCIA, Luiz et al. Inventar com a diferença: cinema e direitos humanos. Niterói: Editora da UFF, 2014. p. 85. Disponível em: < http://goo.gl/JXovJS>. Acesso em: 15 abr. 2016. 